\title{
Comparison of 2-Acetyl-1-Pyrroline (2AP) in Rice Leaf at Different Growth Stages Using Gas Chromatography
}

\author{
Manoch Kongchum ${ }^{1}$, Dustin L. Harrell ${ }^{1}$, Steve D. Linscombe ${ }^{2}$ \\ ${ }^{1}$ H. Rouse Caffey Rice Research Station, Louisiana State University Agricultural Center, Rayne, LA, USA \\ ${ }^{2}$ The Rice Foundation, Arlington, VA, USA \\ Email: *mkongchum@agcenter.lsu.edu
}

How to cite this paper: Kongchum, M., Harrell, D.L. and Linscombe, S.D. (2022) Comparison of 2-Acetyl-1-Pyrroline (2AP) in Rice Leaf at Different Growth Stages Using Gas Chromatography. Agricultural Sciences, 13, 165-176. https://doi.org/10.4236/as.2022.132013

Received: January 11, 2022

Accepted: February 8, 2022

Published: February 11, 2022

Copyright $\odot 2022$ by author(s) and Scientific Research Publishing Inc. This work is licensed under the Creative Commons Attribution International License (CC BY 4.0).

http://creativecommons.org/licenses/by/4.0/

\section{(c) (i) Open Access}

\begin{abstract}
Aromatic rice lines were examined for 2-Acetyl-1-Pyrroline (2AP) content in leaf tissue at five different growth stages (tillering, panicle initiation, 50\% heading, booting, and maturity). A small plot trial with plot size of $1.42 \mathrm{~m} \times$ $4.88 \mathrm{~m}$ (7 row-plots) was arranged in completely randomize design with three replications. Dry-seeded, delayed flood cultural practice was used in this study. The experiment was conducted at three locations. The average $2 \mathrm{AP}$ concentrations in leaf tissue at tillering stages were higher than the other four growth stages. 2AP levels were declined when rice plant reached booting. AP levels decreased slightly at heading stage and decreased significantly at maturity. There was no significant different between $2 \mathrm{AP}$ in leaf at $50 \%$ heading from three locations as well as the $2 \mathrm{AP}$ content in rice grain. Correlations between $2 \mathrm{AP}$ in leaf and $2 \mathrm{AP}$ in grain were significantly in all five growth stages. The highest correlation coefficient was found between $2 \mathrm{AP}$ in leaf at booting and grain $\left(r=0.811^{\star *}\right)$ and lowest was in the leaf at harvest $(\mathrm{r}=$ $0.564^{* *}$ ). Results indicated that $2 \mathrm{AP}$ could be determined in leaf tissue at early growth stage.
\end{abstract}

\section{Keywords}

2-Acetyl-1-Pyrroline (2AP), Aromatic Rice, Leaf Tissue, Gas Chromatography

\section{Introduction}

Aromatic rice varieties are very popular in South and Southeast Asia and have recently gained wider acceptance in the USA and Europe. Due to characteristics 
such as aroma and flavor, they command higher market prices. The aroma quality of aromatic rice in sensory evaluations showed a strong correlation to $2 \mathrm{AP}$ concentration, which is formed in aerial parts of plants during growth in paddy fields. There are several chemical compounds that control the aroma and flavor. Buttery et al. [1] reported that 2AP was a key aroma compound of cooked rice. Subsequently, there have been several studies on identification and determination of 2AP compound [2] [3] [4] [5] [6]. Earlier 2AP analysis methods were concerned with extraction and detection techniques (i.e. solvent-based extraction, headspace, GC-MS). Direct analysis method using cooked rice has been the major 2AP analysis used by many researchers [3] [7] [8]. Recently, a number of researchers have reported the analysis of 2AP directly from uncooked rice [9] [10] [11].

2AP can be analyzed from uncooked rice by various methods with and without chemical extraction technique. Mahatheeranont et al. [9] reported that the quantification of $2 \mathrm{AP}$ in uncooked aromatic rice can be performed by solvent extraction with capillary GC analysis at room temperature. Automated headspace GC analysis method for uncooked aromatic rice without chemical extraction has also been reported [10]. Analysis of 2AP using gas chromatography is a simple and inexpensive method as compared to other techniques. The GC unit used for 2AP analysis comes with headspace sample loading and equipped with flame thermionic detector (FTD) for quantitative analysis in leaf and uncooked rice samples. This method has been developed and has proven to provide as affective method for simple and rapid quantitative of $2 \mathrm{AP}$ in the rice tissue. Recently, it was modified to analyze $2 \mathrm{AP}$ in rice leaf tissue [11].

Not only genetic, but also ecological and cultivation method can highly influence to the 2AP content in rice. Yoshihashi et al. [12] reported that the 2AP levels of Thai aromatic rice variety Khao Dok Mali (KDML) 105 were varied depending on planting locations. Soil conditions can significantly impact level of 2AP. For example, higher level of $2 \mathrm{AP}$ was observed in aromatic rice grown under salinity stress [13] [14]. Nitrogen application at booting can improve grain aroma contents of aromatic rice [15] and application of silicon fertilization in rice can modulate level of $2 \mathrm{AP}$ as well [16]. Lei et al. [17] reported the micro-elements for fragrant rice production were strongly related to $2 \mathrm{AP}$ level. In addition, shading during the grain filing period of aromatic rice significantly improved 2AP content in aromatic rice grain [18]. However, application of growth regulators such as gibberellic acid, indole acetic acid, and paclobutrazol could also significantly decrease aroma [19].

Since it is found in aerial parts, leaf tissue in young rice plant can be used in the breeding process to determine $2 \mathrm{AP}$ content for screening aromatic rice lines. The target aromatic rice lines can be eliminated at early growth stages when $2 \mathrm{AP}$ level is not detected or at very low levels. This technique would save time and materials. In addition, 2AP concentration in the grain can also be quantified once the rice plants reach maturity. 
The objectives of this study were: 1) to compare 2AP concentration in rice leaf tissue from five growth stages (tillering, panicle initiation, booting, 50\% heading, and maturity), and in the rice grain, and 2) to evaluate the effect of planting locations on $2 \mathrm{AP}$ level in leaf tissue at $50 \%$ heading and in grain.

\section{Methods}

\section{Field experiment}

In 2016, twelve aromatic rice lines and a non-aromatic rice cultivar CL153 were examined for 2-Acetyl-1-Pyrroline (2AP) content in leaf tissue at five different growth stages (tillering, panicle initiation, 50\% heading, booting, and maturity). A small plot trial with plot size of $1.42 \mathrm{~m} \times 4.88 \mathrm{~m}$ (7 row-plots) was arranged in completely randomize design with three replications. Dry seeded, delayed flood cultural practice was set up in this study. The experiments were conducted at the Louisiana State University Agricultural Center H. Rouse Caffey Rice Research Station near Crowley and at locations near Lake Arthur, and Mamou, Louisiana. At Lake Arthur and Mamou sites, the leaf samples were collected only at $50 \%$ heading. Grain samples were collected from all three locations. Phosphorus and potassium fertilizer were applied at planting at the rate of $65 \mathrm{~kg} \cdot \mathrm{ha} \mathrm{a}^{-1}$ of $\mathrm{P}_{2} \mathrm{O}_{5}$ and $\mathrm{K}_{2} \mathrm{O}$. Nitrogen was applied one day before flooding at the rate of $135 \mathrm{~kg} \mathrm{~N} \mathrm{ha}^{-1}$. Weed and pest control were applied as needed. Approximately 20 - 25 leaf samples were randomly collected from the $2^{\text {nd }}$ leaf from the top of rice plant in each plot. Leaf and grain of non-aromatic variety CL153 were used as reference standard for 2AP analysis. In addition, grain samples at maturity stage were also collect for $2 \mathrm{AP}$ analysis to evaluate the correlation between $2 \mathrm{AP}$ in the leaf tissue at each growth stage and $2 \mathrm{AP}$ in grain.

In 2017, ten aromatic and one non-aromatic (CL153) lines were included in the study. The trial was conducted at one location, the Louisiana State University Agricultural Center H. Rouse Caffey Rice Research Station near Crowley, Louisiana. Plot sizes, experimental design, number of replications, and sampling schedule were similar to the trial in 2016. Several lines were discarded from the screening process conducted in 2016. Only one line was duplicated for both years, 16CLJ 007 and 17CLPY 1122 in 2016 and 2017, respectively.

\section{Laboratory analysis \\ Leaf Sample preparation:}

Leaf samples were dried at $35^{\circ} \mathrm{C}$ until constant dry weight was observed. The samples were then ground passed $0.25 \mathrm{~mm}$ screen size (sieve no. 60) and keep in a glass vial for gas chromatography analysis. A 0.200 gram of leaf sample was transferred to $20 \mathrm{~mL}$ head space glass vial. $1 \mu \mathrm{L}$ of an external standard $0.5 \mathrm{mg} \cdot \mathrm{mL}^{-1}$ of 2,6-dimethylpyridine was added to the samples, sealed with a heat resistant sealant and then crimped with aluminum cap.

\section{Grain sample preparation:}

Milled rice samples were ground and screened through $0.25 \mathrm{~mm}$ screen size to obtain uniform particle size. Three replications of $1.000 \mathrm{~g}$ of sample were trans- 
ferred into a $20 \mathrm{~mL}$ head space glass vial. One $\mu \mathrm{L}$ of $0.5 \mathrm{mg} \cdot \mathrm{mL}^{-1}$ of 2,6-dimethylpyridine (2,6-DMP) was added to the vial as an internal standard before airtight sealing with a polytetrafluoroethylene/silicone septum secured by an aluminum seal cap.

\section{GC and Headspace condition:}

The gas chromatography and headspace conditions were modified from Sriseadka et al. [10]. Sample vials were placed on the headspace autosampler model HS-20 (Shimadzu, Columbia, MO) and equilibrated at $120^{\circ} \mathrm{C}$ for 10 minutes with high-speed shaking prior to collection of the volatile components. Pressurizing time, pressure equilibrium time, and injection times were 1.00, 0.01 and $2.00 \mathrm{~min}$, respectively. After pressurizing, a sample of head space was collected through a $3-\mathrm{mL}$ sample loop and automatically transferred to the gas chromatograph via a heated transfer line for $0.50 \mathrm{~min}$. The oven, sample line, and transfer line temperatures were set at $120^{\circ} \mathrm{C}, 150^{\circ} \mathrm{C}$, and $160^{\circ} \mathrm{C}$, respectively. Gas chromatographic separation was performed on a Shimadzu GC-2010 Plus system (Shimadzu, Columbia, MO) coupled to a flame thermionic detector (FTD) and equipped with LabSolutions software for data collection and evaluation. Separation was performed using a $60 \mathrm{~m} \times 0.32 \mathrm{~mm}$ i.d. $\times 1.0 \mu \mathrm{m}$ film thickness Rtx- 5 capillary column (Restek, USA), with splitless injection at $250^{\circ} \mathrm{C}$. The temperature of column was programed starting at $50^{\circ} \mathrm{C}$ at the injection, subsequently it was increased at a rate of $5^{\circ} \mathrm{C}$ minute ${ }^{-1}$ from $50^{\circ} \mathrm{C}$ to $200^{\circ} \mathrm{C}$. Gas chromatography/FTD was performed at the temperature of the detector of $280^{\circ} \mathrm{C}$ and using helium as a carrier gas at the flow rate of $3.5 \mathrm{~mL}$ minute $^{-1}$.

The concentration of 2-Acetyl-1-pyrroline (2AP) was identified by the gas chromatography retention times relative to the standard run under the same conditions. Peak areas were obtained with the aid of LabSolutions software.

Preparation of Standard:

A standard of $10 \mathrm{mg}$ of 2-Acetyl-1-pyrroline in a $10 \% \mathrm{w} / \mathrm{w}$ in toluene was purchased from Toronto Research Chemicals (TRC), Canada. A series of standards at the concentration of $0,0.5,1.0,1.25,2.5,5.0 \mu \mathrm{g} \cdot \mathrm{g}^{-1}$ of $2 \mathrm{AP}$ in toluene was prepared. A non-aromatic CL153 milled rice sample was ground into a powder in the same manner with the aromatic samples. Three replications of $1.000 \mathrm{~g}$ of non-aromatic milled rice were weighed and transferred into a $20 \mathrm{~mL}$ head space glass vial for each level of standard. One $\mu \mathrm{L}$ of $0.5 \mathrm{mg} / \mathrm{mL}$ of 2,6-dimethylpyridine (2,6-DMP) and $1 \mu \mathrm{L}$ of $2 \mathrm{AP}$ standard of each concentration level were added into the vial before airtight sealing with a polytetrafluoroethylene/silicone septum secured by an aluminum cap. The headspace autosampler and gas chromatography set up and analysis were performed in the same manner with the samples that were mentioned above. For leaf samples, $0.200 \mathrm{~g}$ of non-aromatic rice leaf samples (CL153) that were collected at the same sampling time of each growth stage were used as a background of each standard set. Other steps were done in the same manner with the preparation of standard set for 2AP analysis in the grain samples described above. A GC Chromatogram of $2 \mathrm{AP}$ analysis is showed in Figure 1. 


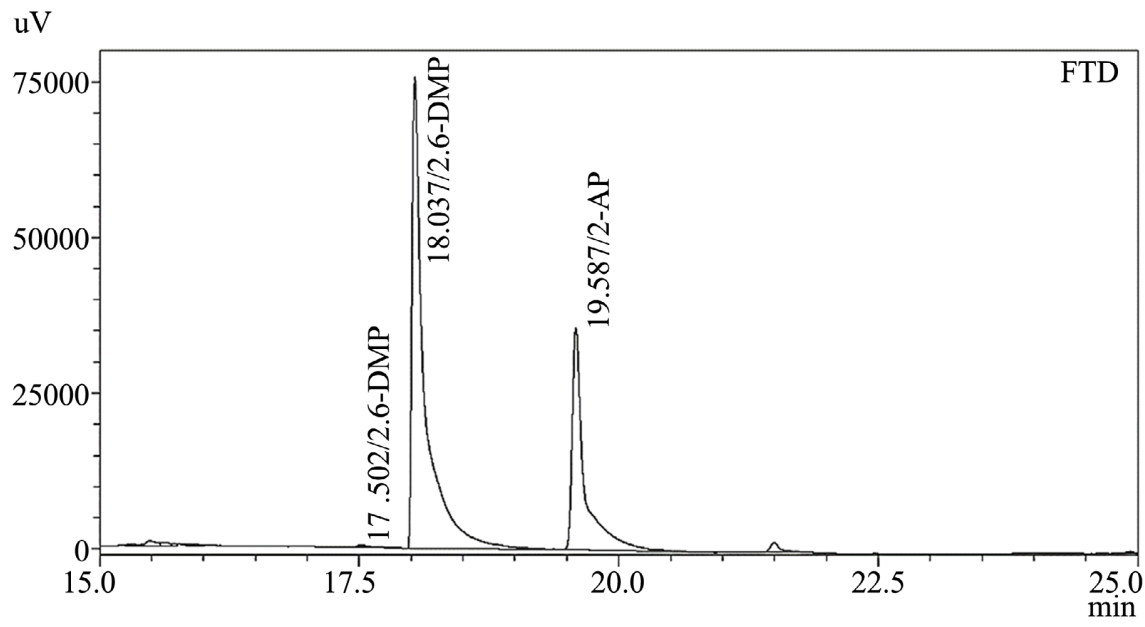

Figure 1. GC Chromatogram of 2AP in grain of 16CLJ 007 (CLJ 01) line when using 2,6-DMP as an internal standard.

\section{Results and Discussions}

\section{$2 A P$ in rice leaf tissue}

Even though $2 \mathrm{AP}$ is not the only compound that controls aroma quality, it has been used as a main indicator for aromatic quality comparison because it not detected in non-aromatic rice [1]. Aroma volatile compounds consist of several compound such as aldehydes, ketones, sulfur compounds, alcohols, heterocyclics, ester, alkanes, alkenes, ketones, amines, and miscellaneous compounds [8] [20]. Thus, higher $2 \mathrm{AP}$ contents may not always reflect a better aroma quality. In this study, twelve aromatic and three non-aromatic lines were included for screening of aromatic rice lines. The lowest average $2 \mathrm{AP}$ concentration in rice leaf tissue was $0.77 \mu \mathrm{g} \cdot \mathrm{g}^{-1}$ at maturity was from the line 16CLJ004 and the highest was $5.21 \mu \mathrm{g} \cdot \mathrm{g}^{-1}$ at the panicle initiation stage from the line 16CLJ005 (Table 1). The average concentration overall of the 12 aromatic lines in the leaf tissue decreased at the later growth stages. The highest was detected at tillering (4.01 $\left.\mu \mathrm{g} \cdot \mathrm{g}^{-1}\right)$ followed by at panicle initiation $\left(3.50 \mu \mathrm{g} \cdot \mathrm{g}^{-1}\right)$, booting $\left(2.69 \mu \mathrm{g} \cdot \mathrm{g}^{-1}\right), 50 \%$ heading $\left(2.20 \mu \mathrm{g} \cdot \mathrm{g}^{-1}\right)$, and the lowest was detected at maturity $\left(1.27 \mu \mathrm{g} \cdot \mathrm{g}^{-1}\right)$ (Figure 2). The concentrations of $2 \mathrm{AP}$ in leaf tissue were not in uniformed distribution. Hinge et al. (2016) reported that 2AP in leaf tissue from two basmati cultivars increased from seedling until booting stages. However, in this study 2AP in leaf tissue of some lines increased from tillering to panicle initiation stages and started decreasing at booting stage, and the majority lines showed decreases from tillering to booting stage.

At $50 \%$ heading, leaf samples were collected from the three locations. The average $2 \mathrm{AP}$ concentrations from 12 lines were $2.20 \mu \mathrm{g} \cdot \mathrm{g}^{-1}$ at Crowley and Lake Arthur, and $2.56 \mu \mathrm{g} \cdot \mathrm{g}^{-1}$ at Mamou (Figure 3). The concentration of leaf 2AP in the same line was higher in $2016\left(2.51 \mu \mathrm{g} \cdot \mathrm{g}^{-1}\right)$ as compared to $2.20 \mu \mathrm{g} \cdot \mathrm{g}^{-1}$ in 2017. The different could be due to several factors such as air temperature, soil type [11] water stress [21] and shading [18]. 


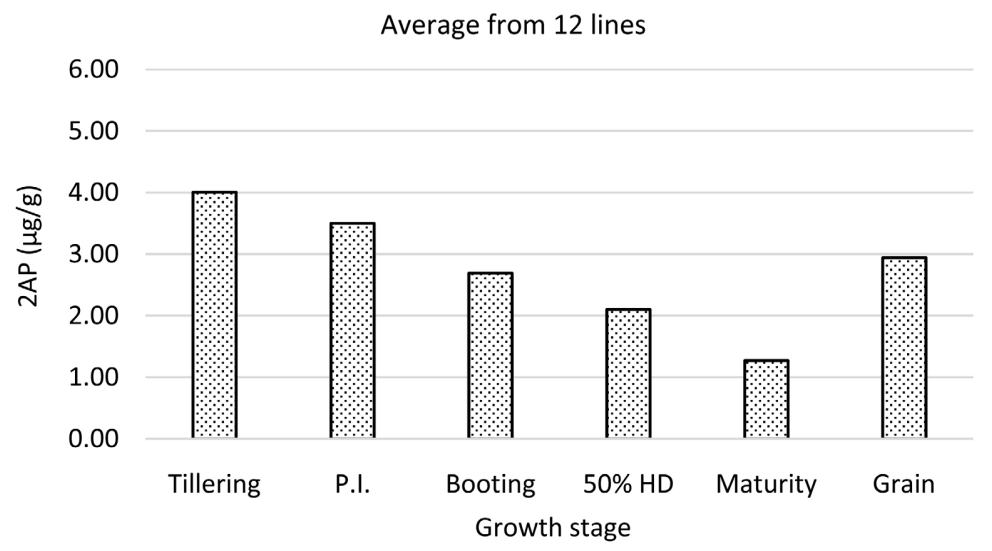

Figure 2. Effect of growth stages on $2 \mathrm{AP}$ concentration in rice leaf tissue and in grain in 2016 average from 12 lines. Data from 50\% heading and in grain were averaged from 12 lines from three locations.

Table 1. Leaf 2AP concentration $\left(\mu \mathrm{g} \cdot \mathrm{g}^{-1}\right.$ ) of 12 aromatic lines and a non-aromatic cultivar CL153 at tillering, panicle initiation (P.I.), booting, 50\% heading, maturity, and $2 \mathrm{AP}$ in grain. Samples at 50\% heading and in grain were collected from 3 locations (Crowley, Lake Arthur, and Mamou) in Louisiana in 2016.

\begin{tabular}{|c|c|c|c|c|c|c|c|c|c|c|c|c|c|c|c|}
\hline \multirow{3}{*}{$\begin{array}{l}\text { Entries } \\
\text { 6CLJ } 001\end{array}$} & \multirow{3}{*}{\multicolumn{2}{|c|}{$\begin{array}{l}\text { Tillering } \\
\\
4.56 \quad \mathrm{ab}\end{array}$}} & \multicolumn{2}{|c|}{ P.I. } & \multicolumn{2}{|c|}{ Booting } & \multicolumn{2}{|c|}{ Maturity } & \multicolumn{4}{|c|}{$50 \%$ Heading } & \multicolumn{3}{|c|}{ Grain } \\
\hline & & & \multicolumn{4}{|c|}{ Crowley } & \multirow[b]{2}{*}{1.75} & \multirow[b]{2}{*}{$\mathrm{ab}$} & \multicolumn{2}{|c|}{ Crowley } & $\begin{array}{l}\text { Lake } \\
\text { Arthur }\end{array}$ & Mamou & Crowley & $\begin{array}{l}\text { Lake } \\
\text { Arthur }\end{array}$ & Mamou \\
\hline & & & 3.66 & bcd & 3.29 & $\mathrm{a}$ & & & 1.86 & $\mathrm{~b}$ & $2.28 \mathrm{abc}$ & 1.82 & $3.43 \mathrm{bc}$ & $2.74 \mathrm{~cd}$ & $2.70 \mathrm{de}$ \\
\hline 16CLJ 002 & 3.39 & $\mathrm{~cd}$ & 3.35 & $\mathrm{~cd}$ & 2.26 & $\mathrm{~cd}$ & 1.96 & $\mathrm{a}$ & 2.43 & $\mathrm{ab}$ & $1.99 \mathrm{abc}$ & $2.42 \mathrm{abc}$ & $3.07 \mathrm{de}$ & $1.76 \mathrm{f}$ & $2.97 \mathrm{c}$ \\
\hline 16CLJ 003 & 2.93 & $\mathrm{~d}$ & 2.98 & $\mathrm{~cd}$ & 2.88 & $\mathrm{abc}$ & 1.53 & $\mathrm{abc}$ & 1.95 & $\mathrm{~b}$ & $1.97 \mathrm{abc}$ & $2.52 \mathrm{abc}$ & $2.28 \mathrm{f}$ & $1.41 \mathrm{~g}$ & $2.62 \mathrm{de}$ \\
\hline 16CLJ 004 & 3.61 & bcd & 3.18 & $\mathrm{~cd}$ & 1.88 & d & 0.77 & $\mathrm{de}$ & 1.84 & $\mathrm{~b}$ & $2.90 \mathrm{ab}$ & $2.99 \mathrm{ab}$ & 2.85 & $1.64 \mathrm{fg}$ & $2.63 \mathrm{de}$ \\
\hline 16CLJ 005 & 5.21 & a & 3.56 & bcd & 2.36 & bcd & 1.22 & $a-d$ & 1.94 & $\mathrm{~b}$ & $2.04 \mathrm{abc}$ & $2.21 \mathrm{bc}$ & 2.25 & $1.86 \mathrm{f}$ & $2.35 \mathrm{f}$ \\
\hline 16CLJ 006 & 3.34 & $\mathrm{~cd}$ & 3.55 & bcd & 2.59 & $a-d$ & 1.16 & bcd & 2.49 & $\mathrm{ab}$ & $2.11 \mathrm{abc}$ & $2.36 \mathrm{abc}$ & 1.38 & $1.42 \mathrm{~g}$ & $1.70 \mathrm{~g}$ \\
\hline $16 \mathrm{CLJ} 007^{\star}$ & 5.19 & a & 4.89 & $\mathrm{a}$ & 3.24 & $\mathrm{ab}$ & 1.32 & $a-d$ & 2.51 & $\mathrm{ab}$ & 2.93 & $3.34 \quad \mathrm{a}$ & $3.73 \mathrm{ab}$ & $3.80 \mathrm{a}$ & $3.70 \quad b$ \\
\hline 16CLJ 008 & 4.46 & $a b c$ & 4.65 & $\mathrm{ab}$ & 3.15 & $a b c$ & 1.09 & bcd & 2.84 & $\mathrm{a}$ & $2.45 \mathrm{abc}$ & $3.22 \mathrm{ab}$ & $3.28 \mathrm{~cd}$ & $2.85 \mathrm{bc}$ & 2.47 ef \\
\hline 16CLJ 009 & 4.85 & a & 2.96 & $\mathrm{~cd}$ & 2.61 & $a-d$ & 1.41 & $a-d$ & 2.28 & $\mathrm{ab}$ & $2.05 \mathrm{abc}$ & $2.26 \mathrm{bc}$ & $3.02 \mathrm{de}$ & $2.60 \mathrm{~d}$ & $2.80 \mathrm{~cd}$ \\
\hline 16CLJ 010 & 3.50 & bcd & 2.52 & $\mathrm{~d}$ & 2.42 & $a-d$ & 1.19 & bcd & 2.18 & $\mathrm{ab}$ & $1.86 \mathrm{bc}$ & $2.68 \mathrm{abc}$ & 3.81 & $2.26 \mathrm{e}$ & $3.97 \mathrm{a}$ \\
\hline 16CLJ 011 & 3.55 & bcd & 2.90 & $c d$ & 2.41 & $a-d$ & 1.05 & bcd & 1.80 & $\mathrm{~b}$ & 1.80 & $2.33 \mathrm{abc}$ & $2.72 \mathrm{e}$ & $2.25 \mathrm{e}$ & $2.98 \mathrm{c}$ \\
\hline 16CLJ 012 & 3.49 & bcd & 3.83 & $\mathrm{abc}$ & 3.21 & $\mathrm{ab}$ & 0.86 & cde & 2.29 & $a b$ & $1.99 \mathrm{abc}$ & $2.56 \mathrm{abc}$ & $3.48 \mathrm{abc}$ & $2.99 \mathrm{~b}$ & $2.77 \mathrm{~cd}$ \\
\hline CL153 (Check) & 0.02 & $\mathrm{e}$ & 0.01 & $\mathrm{e}$ & 0.01 & $\mathrm{e}$ & 0.01 & $\mathrm{e}$ & 0.01 & c & $0.01 \quad \mathrm{~d}$ & $0.01 \quad \mathrm{~d}$ & $0.00 \mathrm{~h}$ & $0.00 \mathrm{~h}$ & $0.00 \mathrm{~h}$ \\
\hline LSD P $=0.05$ & 1.1 & & 1.1 & & 0.90 & & 0.7 & & 0.7 & & 1.070 & 1.045 & 0.303 & 0.243 & 0.239 \\
\hline S. D. & 0.6 & & 0.7 & & 0.5 & & 0.4 & & 0.4 & & 0.640 & 0.625 & 0.181 & 0.145 & 0.143 \\
\hline $\mathrm{CV}$ & 21 & & 24. & & 24.7 & & 42. & & 25.0 & & 35.5 & 29.63 & 7.35 & 7.81 & 6.32 \\
\hline Treatment F & 19 & & 15. & & 12. & & 4.2 & & 7.48 & & 5.729 & 7.88 & 110.5 & 177.1 & 223.5 \\
\hline Prob (F) & 0.0 & & 0.00 & 01 & 0.00 & 01 & 0.00 & & 0.00 & & 0.0001 & 0.0001 & 0.0001 & 0.0001 & 0.0001 \\
\hline
\end{tabular}

Means followed by same letter or symbol do not significantly differ ( $\mathrm{P}=0.05$, LSD). The line CLJ 007 was released as "CLJ01" cultivar in 2019, Louisiana State University Agricultural Center. ${ }^{\star}$ Concentration below $0.001 \mu \mathrm{g} \cdot \mathrm{g}^{-1}$. 


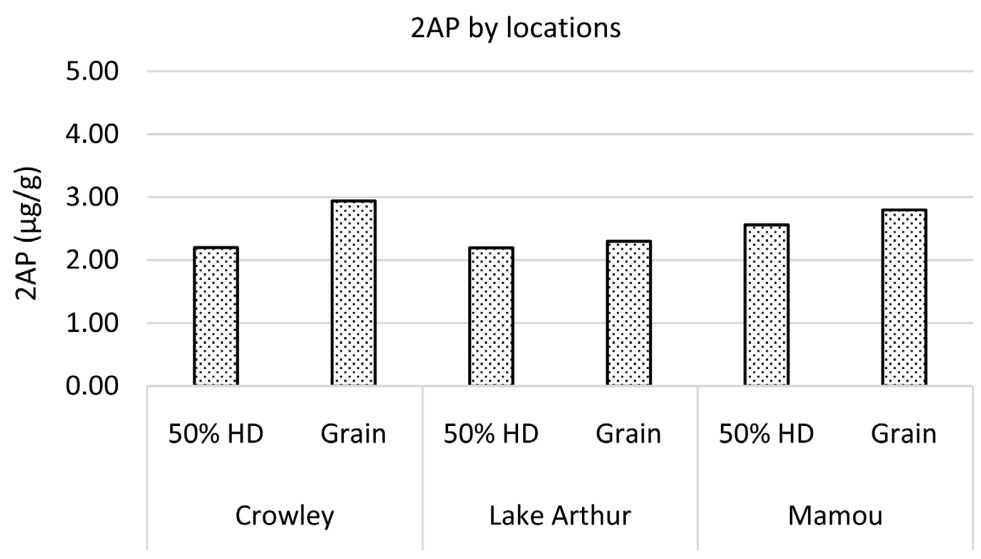

Figure 3. Effect of locations on $2 \mathrm{AP}$ concentration in rice leaf at $50 \%$ heading and in grain average from 12 lines and 3 locations.

Many of the advance aromatic lines from the 2016 trial were not continued in the 2017 trial. However, the line \#16CLJ 007 was selected to be included in the 2017 trial with the new name (17CLPY 1122). An addition nine aromatic lines were selected to be included in the analysis for $2 \mathrm{AP}$ in both leaf and grain in 2017. Therefore, these additional lines were not repeated. The average concentrations of 2AP in leaf tissue were similar with the trial conducted in 2016, which decreased at later growing states. The highest concentration was observed at tillering $\left(3.30 \mu \mathrm{g} \cdot \mathrm{g}^{-1}\right)$, and the lowest was at the maturity stage $\left(1.09 \mu \mathrm{g} \cdot \mathrm{g}^{-1}\right)$ (Figure 4).

The 16CLJ007 line in 2016 (16CLJ007) was identical with 17CLPY1122 in 2017. It was included for the $2 \mathrm{AP}$ analysis in both years. Subsequently, this line was released as variety CLJ01 in 2019 [22]. Even though 2AP in each growth stage was not exactly the same concentration, the average of $2 \mathrm{AP}$ level in leaf for both years had similar patterns, which was highest at tillering and was lowest at maturity. The levels of 2AP in all growth stages including in grain in 2016 were slightly higher than that of 2017 (Figure 5).

In 2016, the levels of 2AP of most aromatic lines (8 of 12 lines) were highest at tillering, while in another 4 lines the highest levels were detected at panicle initiation. However, all twelve lines decreased to the lowest levels at maturity. In 2017, 2AP concentration from 6 of 10 lines was highest at tillering, 2 of 10 lines were highest at P.I, and another 2 of 10 lines were highest at the booting stage (Table 2). The lowest levels for all lines were observed at maturity. The decline at reproductive stages could be because of the translocation of $2 \mathrm{AP}$ from leaf and to the grain [14] [23].

$2 A P$ in grain

Grain 2AP levels from 12 aromatic lines in the 2016 trial are showed in Table 1. The concentration varied from $1.38-3.81 \mu \mathrm{g} \cdot \mathrm{g}^{-1}$ at $\mathrm{H}$. Rouse Caffey Rice Research Station site, $1.41-3.80 \mu \mathrm{g} \cdot \mathrm{g}^{-1}$ at Lake Arthur, and $1.70-3.97 \mu \mathrm{g} \cdot \mathrm{g}^{-1}$ at Mamou. Average concentration of $2 \mathrm{AP}$ over all lines in grain $\left(2.94 \mu \mathrm{g} \cdot \mathrm{g}^{-1}\right)$ was 


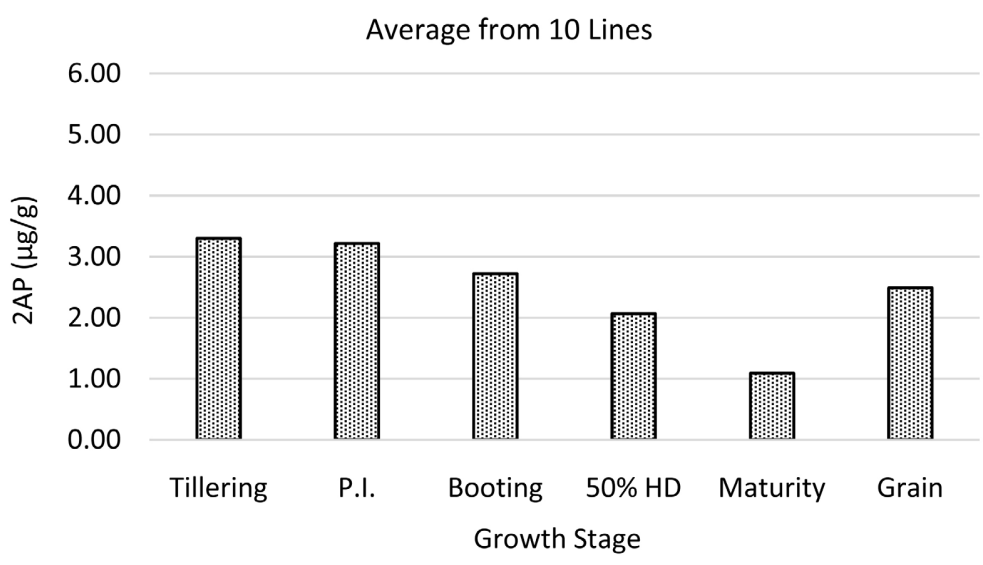

Figure 4. Effect of growth stages on $2 \mathrm{AP}$ concentration in rice leaf tissue and grain. Average from 10 lines, H. Rouse Caffey Rice Research Station, Crowley, 2017.

CL 01

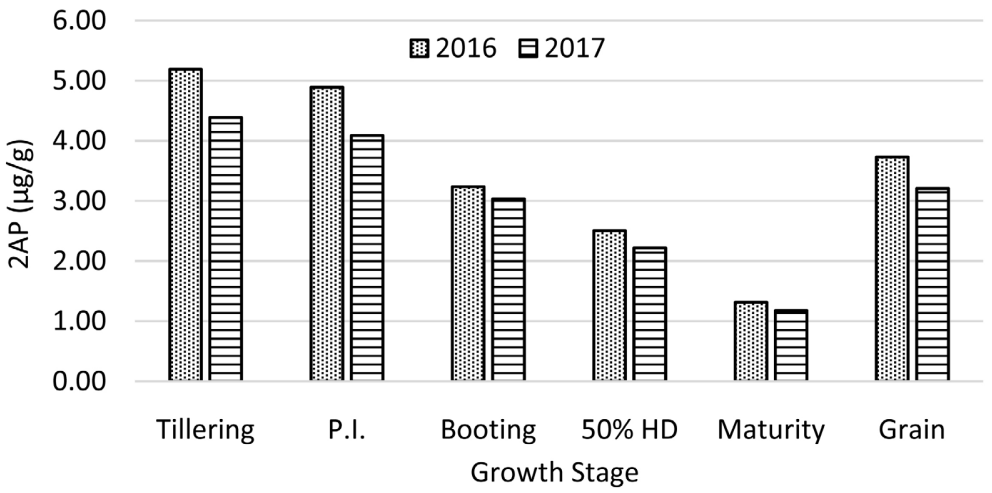

Figure 5. Distribution of 2AP in leaf from various growth stages and grain of CLJ01 in 2016 and 2017.

lower than in the leaf tissue at tillering $\left(4.01 \mu \mathrm{g} \cdot \mathrm{g}^{-1}\right)$, and panicle initiation (3.50 $\left.\mu \mathrm{g} \cdot \mathrm{g}^{-1}\right)$ stages but it was higher than the concentration at booting $\left(2.69 \mu \mathrm{g} \cdot \mathrm{g}^{-1}\right)$, and maturity stage $\left(1.27 \mu \mathrm{g} \cdot \mathrm{g}^{-1}\right)$.

In 2017, the overall average of $2 \mathrm{AP}$ in grain from 10 aromatic lines (Table 2) was $2.49 \mu \mathrm{g} \cdot \mathrm{g}^{-1}$ (ranged from $2.09-3.21 \mu \mathrm{g} \cdot \mathrm{g}^{-1}$ ). It was lower than the average concentration in leaf tissue at tillering $\left(3.30 \mu \mathrm{g} \cdot \mathrm{g}^{-1}\right)$, at panicle initiation (3.22 $\left.\mu \mathrm{g} \cdot \mathrm{g}^{-1}\right)$ and booting $\left(2.72 \mu \mathrm{g} \cdot \mathrm{g}^{-1}\right)$ but it was higher than $50 \%$ heading $\left(2.07 \mu \mathrm{g} \cdot \mathrm{g}^{-1}\right)$, and maturity $\left(1.09 \mu \mathrm{g} \cdot \mathrm{g}^{-1}\right)$. The $2 \mathrm{AP}$ levels in rice grain in both years were lower than the 2AP in leaf tissue. The study of Boontakham et al. [11] found that the leaf tissue 2AP concentration of KDML 105 ranged from $3.08-16.39 \mu \mathrm{g} \cdot \mathrm{g}^{-1}$ while the concentration in the grain ranged from $2.87-4.01 \mu \mathrm{g} \cdot \mathrm{g}^{-1}$.

Correlation between $2 A P$ in leaf and grain

Correlations between $2 \mathrm{AP}$ in leaf tissue and in grain were highly significant at all three locations and for both years. The highest correlation between 2AP in leaf tissue and grain at the Crowley location was observed at the booting stage ( $\mathrm{r}$ $\left.=0.811^{\star *}\right)$. Since there were no data for leaf $2 \mathrm{AP}$ at all five growth stages, the 
Table 2. Leaf 2AP concentration $\left(\mu \mathrm{g} \cdot \mathrm{g}^{-1}\right)$ in leaf tissue at different growth stages and in grain. LSU Ag center rice research station, Crowley, 2017.

\begin{tabular}{|c|c|c|c|c|c|c|c|c|c|c|c|c|}
\hline \multirow{2}{*}{$\begin{array}{c}\text { Entries } \\
\text { 17CLPY } 1090\end{array}$} & \multicolumn{2}{|c|}{ Tillering } & \multicolumn{2}{|c|}{ P.I. } & \multicolumn{2}{|c|}{ Booting } & \multicolumn{2}{|c|}{$50 \% \mathrm{HD}$} & \multicolumn{2}{|c|}{ Maturity } & \multicolumn{2}{|c|}{ Grain } \\
\hline & 2.49 & de & 3.13 & c & 2.21 & $\mathrm{e}$ & 1.98 & $\mathrm{~d}$ & 0.93 & c & 2.34 & bcd \\
\hline 17CLPY 1096 & 3.14 & c & 2.55 & $\mathrm{~d}$ & 2.29 & de & 1.49 & e & 1.07 & $a b c$ & 2.09 & $\mathrm{e}$ \\
\hline 17CLPY 1097 & 2.95 & $\mathrm{~cd}$ & 2.95 & c & 3.18 & $\mathrm{a}$ & 2.17 & $\mathrm{~cd}$ & 1.13 & $a b c$ & 2.28 & $\mathrm{~cd}$ \\
\hline 17CLPY 1101 & 2.14 & e & 2.42 & $\mathrm{~d}$ & 2.53 & $\mathrm{~cd}$ & 1.49 & e & 1.14 & $a b c$ & 2.45 & $\mathrm{bc}$ \\
\hline 17CLPY 1102 & 3.49 & bc & 3.47 & $\mathrm{~b}$ & 2.76 & bc & 2.66 & $\mathrm{a}$ & 1.10 & $a b c$ & 2.15 & $\mathrm{de}$ \\
\hline 17CLPY 1103 & 4.11 & $\mathrm{a}$ & 3.58 & $\mathrm{~b}$ & 2.56 & $\mathrm{~cd}$ & 1.67 & e & 1.02 & $\mathrm{bc}$ & 2.38 & $\mathrm{bc}$ \\
\hline 17CLPY 1104 & 3.85 & $a b$ & 2.93 & c & 2.71 & $c$ & 2.04 & $\mathrm{~d}$ & 0.91 & c & 3.17 & $\mathrm{a}$ \\
\hline 17CLPY 1107 & 3.19 & c & 4.04 & $\mathrm{a}$ & 3.34 & $\mathrm{a}$ & 2.61 & $\mathrm{ab}$ & 1.12 & $a b c$ & 2.48 & $\mathrm{~b}$ \\
\hline 17CLPY 1112 & 3.28 & $\mathrm{bc}$ & 2.96 & c & 2.62 & $c$ & 2.34 & $\mathrm{bc}$ & 1.31 & $\mathrm{a}$ & 2.32 & bcd \\
\hline 17CLPY 1122 & 4.39 & $\mathrm{a}$ & 4.09 & $\mathrm{a}$ & 3.04 & $\mathrm{ab}$ & 2.22 & $\mathrm{~cd}$ & 1.18 & $\mathrm{ab}$ & 3.21 & $\mathrm{a}$ \\
\hline CL153 (Check) & 0.01 & $\mathrm{f}$ & 0.01 & $\mathrm{e}$ & $0.00^{*}$ & $f$ & $0.00^{*}$ & $\mathrm{f}$ & $0.00^{\star}$ & $\mathrm{d}$ & $0.00^{*}$ & $\mathrm{f}$ \\
\hline LSD P $=0.05$ & 0.587 & & 0.302 & & 0.302 & & 0.294 & & 0.2479 & & 0.193 & \\
\hline S.D. & 0.345 & & 0.177 & & 0.177 & & 0.173 & & 0.1456 & & 0.113 & \\
\hline $\mathrm{CV}$ & 11.41 & & 6.05 & & 7.12 & & 9.13 & & 14.55 & & 4.99 & \\
\hline Treatment F & 33.34 & & 108.57 & & 69.22 & & 51.32 & & 14.50 & & 156.21 & \\
\hline Prob (F) & 0.0001 & & 0.0001 & & 0.0001 & & 0.0001 & & 0.0001 & & 0.0001 & \\
\hline
\end{tabular}

Means followed by same letter or symbol do not significantly differ $(\mathrm{P}=0.05$, LSD). P.I. = panicle initiation, $17 \mathrm{CLPY} 1122$ was released as "CLJ 01" cultivar in 2019. ${ }^{\star}$ Concentration below $0.001 \mu \mathrm{g} \cdot \mathrm{g}^{-1}$.

correlation between $2 \mathrm{AP}$ in leaf tissue at $50 \%$ heading and grain at Lake Arthur and Mamou was $0.709^{* *}$, and $0.767^{* *}$, respectively.

Effect of location on $2 A P$ concentration

Only $2 \mathrm{AP}$ in leaf tissue at $50 \%$ heading and in grain were analyzed at all three locations in 2016. The concentration varied by locations and rice lines (Figure 5). Since this compound can be related to many factors, variation in environmental factors can influence 2AP accumulation. Environmental factors have long been noted: for example, Efferson [24] stated that the Basmati rice was fragrance-free when grown in some regions in India. In recent research, Boontakham et al. [11] reported that the leaf 2AP of KDML 105 was significantly higher when grown in lower temperatures and responded differently by cultivars. The cooler temperature during the ripening stage was found to have better aroma [25]. In addition, soil type could influence the concentration of $2 \mathrm{AP}$ in some cultivars. KDML 105 grown in clay loam soil had higher a content than when grown in sandy loam soil [11] but it did not impact another aromatic rice culti$\operatorname{var}($ PTT 1). 


\section{Conclusion}

The 2AP compound could be determined in leaf tissue at early growth stage. The best correlation between $2 \mathrm{AP}$ in leaf and in grain was found at booting stage. The concentration was declined when the rice reached the reproductive stage. This could be due to the translocation of $2 \mathrm{AP}$ from leaf and other plant parts to the grain. 2AP levels seem to vary by locations but are not significantly different. The result from this study indicates that the analysis of 2AP in rice leaf tissue can be used for screening aromatic rice lines from non-aromatic lines at early growth stages, which could lower costs and increase effectiveness in breeding programs.

\section{Acknowledgements}

This research was partially supported by Louisiana Rice Research Board.

\section{Conflicts of Interest}

The authors declare no conflicts of interest regarding the publication of this paper.

\section{References}

[1] Buttery, R.G., Juliano, B.O. and Ling, L.C. (1983) Identification of Rice Aroma Compound 2-Acetyl-1-Pyrroline in Pandan Leaves. Chemistry \& Industry, 23, 478.

[2] Buttery, R.G., Ling, L.C. and Juliano, B.O. (1982) 2-Acetyl-1-Pyrroline: An Important Aroma Component of Cooked Rice. Chemistry \& Industry, 22, 958-959.

[3] Buttery, R.G., Turnbaugh, J.G. and Ling, L.C. (1988) Contribution of Volatiles to Rice Aroma. Journal of Agricultural and Food Chemistry, 36, 1006-1009. https://doi.org/10.1021/jf00083a025

[4] Paule, C.M. and Powers, J.J. (1989) Sensory and Chemical Examination of Aromatic and Nonaromatic Rice. Journal of Food Science, 54, 343-346. https://doi.org/10.1111/j.1365-2621.1989.tb03076.x

[5] Lin, C.F., Hsieh, T.C.Y. and Hoff, B.J. (1990) Identification and Quantification of the "Popcorn"-Like Aroma, in Louisiana Aromatic Della Rice (Oryza sativa L.). Journal of Food Science, 55, 1466-1467. https://doi.org/10.1111/j.1365-2621.1990.tb03961.x

[6] Laksanalamai, V. and Ilangantileke, S. (1993) Comparison of Aroma Compound (2-Acetyl-1-Pyrroline) in Leaves in Pandan (Pandanus amaryllifolius) and Thai Fragrant Rice (Khao Dawk Mali-105). Cereal Chemistry, 70, 381-384.

[7] Jezussek, M., Juliano, B.O. and Schieberle, P. (2002) Comparison of Key Aroma Compounds in Cooked Brown Rice Varieties Based on Aroma Extract Dilution Analyses. Journal of Agricultural and Food Chemistry, 50, 1101-1105. https://doi.org/10.1021/jf0108720

[8] Mahattanatawee, K. and Rouseff, R.L. (2014) Comparison of Aroma Active and Sulfur Volatiles in Three Fragrant Rice Cultivars Using GC-Olfactometry and GC-PFPD. Food Chemistry, 154, 1-6. https://doi.org/10.1016/j.foodchem.2013.12.105

[9] Mahatheeranont, S., Keawsa-ard, S. and Dumri, K. (2001) Quantification of the Rice Aroma Compound, 2-Acetyl-1-Pyrroline, in Uncooked Khao Dawk Mali 105 Brown 
Rice. Journal of Agricultural and Food Chemistry, 49, 773-779. https://doi.org/10.1021/jf000885y

[10] Sriseadka, T., Wongpornchai, S. and Kitsawatpaiboon, P. (2006) Rapid Method for Quantitative Analysis of the Aroma Impact Compound, 2-Acetyl-1-Pyrroline, in Fragrant Rice Using Automated Headspace Gas Chromatography. Journal of Agricultural and Food Chemistry, 54, 8183-8189. https://doi.org/10.1021/jf0614490

[11] Boontakham, P., Sookwong, P., Jongkaewwattana, S., Wangtueai, S. and Mahatheeranont, S. (2019) Comparison of Grain Yield and 2-Acetyl-1-Pyrroline (2AP) Content in Leaves and Grain of Two Thai Fragrant Rice Cultivar Cultivated at Greenhouse and Open-Air Conditions. Australian Journal of Crop Science, 13, 159-169. https://doi.org/10.21475/ajcs.19.13.01.p1431

[12] Yoshihashi, T., Nguyen, T.T.H. and Kabaki, N. (2004) Area Dependency of 2-Acetyl-1-Pyrroline Content in an Aromatic Rice Variety, Khao Dawk Mali 105. Japan Agricultural Research Quarterly, 38, 105-109.

[13] Gay, F., Maraval, I., Roques, S., Gunata, Z., Boulanger, R. and Audebert, A. (2010) Effect of Salinity on Yield and 2-Acetyl-1-Pyrroline Content in the Grains of Three Fragrant Rice Cultivars (Oryza sativa L.) in Camargue (France). Field Crops Research, 117, 154-160. https://doi.org/10.1016/j.fcr.2010.02.008

[14] Poonlaphdecha, J., Maraval, I., Roques, S., Audebert, A., Boulanger, R., Bry, X. and Gunata, Z. (2012) Effect of Timing and Duration of Salt Treatment during Growth of Fragrant Rice Variety on Yield and 2-Acetyl-1-Pyrroline, Proline and GABA Levels. Journal of Agricultural and Food Chemistry, 60, 3824-3830. https://doi.org/10.1021/jf205130y

[15] Mo, Z., Ashraf, U., Tang, Y., Li, W., Pan, S., Duan, M., Tian, H. and Tang, X. (2018) Nitrogen Application at the Booting State Affects 2-Acetyl-1-Pyrroline, Proline and Total Nitrogen Contents in Aromatic Rice. Chilean Journal of Agricultural Research, 78, 165-172.

[16] Mo, Z., Lei, S., Ashraf, U., Khan, I., Li, Y., Pan, S., Duan, M., Tian, H. and Tang, X. (2017) Silicon Fertilization Modulates 2-Acetyl-1-Pyrroline Content, Yield Formation and Grain Quality of Aromatic Rice. Journal of Cereal Science, 75, 17-24. https://doi.org/10.1016/j.jcs.2017.03.014

[17] Lei, S, Wang, C.C., Ashraf, U., Mo, Z.W, Namaw, M., Ashraf, I., Muzaffar, W., Liu, S.J. and Tang, X.R. (2017) Exogenous Application of Mixed Micro-Nutrients Improves Yield, Quality and 2-Acetyl-1-Pyrroline Contents in Fragrant Rice. Applied Ecology and Environmental Research, 15, 1097-1109. https://doi.org/10.15666/aeer/1503 10971109

[18] Mo, Z., Li, W., Pan, S., Frtzgerald, T.L., Xiao, F., Tang, Y., Wang, Y., Duan, M., Tian, H. and Tang, X. (2015) Shading during the Grain Filling Period Increases 2-Acetyl-1-Pyrroline Content in Fragrant Rice. Rice, 8, Article No. 9. https://doi.org/10.1186/s12284-015-0040-y

[19] Goufo, P., Wonpornchai, S. and Tang, X. (2011) Decrease in Rice Aroma after Application of Growth Regulators. Agronomy for Sustainable Development, 31, 349-359. https://doi.org/10.1051/agro/2010011

[20] Bryant, R.J. and McClung, A.M. (2011) Volatile Profiles of Aromatic and Non-Aromatic Rice Cultivars Using SPME/GC-MS. Food Chemistry, 124, 501-513. https://doi.org/10.1016/j.foodchem.2010.06.061

[21] Yoshihashi, T., Kabaki, N., Nguyen, T.T.H. and Inatomi, H. (2002) Formation of Flavor Compound in Aromatic Rice and Its Fluctuations with Drought Stress. Research Highlights JIRCAS 2002-2003, Tsukuba, 32-33. 
[22] Famoso, A.F., Harrell, D.L., Groth, D.G., Kongchum, M., Wenefrida, I., Oard, J.H., Zaunbrecher, R.E., Bearb, K.F., Conner, C.A, Guidry, G.J., Angira, B.A., Sha, X. and Linscombe, S.D. (2019) Registration of 'CLJ01' Rice. Journal of Plant Registrations, 13, 143-147. https://doi.org/10.3198/jpr2018.06.0035crc

[23] Hinge, V.R., Patil, H.B. and Nadaf, A.B. (2016) Aroma Volatile Analyses and 2AP Characterization at Various Developmental Stages in Basmati and No-Basmati Scented Rice (Oryza sativa L.) Cultivars. Rice, 9, Article No. 38.

https://doi.org/10.1186/s12284-016-0113-6

[24] Efferson, J.N. (1985) Rice Quality in World Markets. In: Bostian, L.R., Ed., Rice Grain Quality and Marketing, International Rice Research Institute, Manila, 1-13.

[25] Dela Cruz, N., Kumar, I., Kaushik, R.P. and Khush, G.S. (1989) Effect of Temperature during Grain Development on Stability of Cooking Quality Components in Rice. Japanese Journal of Breeding, 39, 299-306. 